\title{
Maternally inherited coronary heart disease is associated with a novel mitochondrial tRNA mutation
}

\author{
Zhenxiao Zhang' ${ }^{1}$ Mingyang Liu', Jianshuai He${ }^{2}$, Xiaotian Zhang ${ }^{2}$, Yuehua Chen ${ }^{3}$ and Hui Li ${ }^{1^{*}}$ (D)
}

\begin{abstract}
Background: Coronary heart disease (CHD) is the most common cause of mortality globally, yet mitochondrial genetic mutations associated with CHD development remain incompletely understood.

Methods: The subjects from three Chinese families with LHON underwent clinical, genetic, molecular, and biochemical evaluations. Biochemical characterizations included measuring the effects of the $15910 \mathrm{C}>$ T mutation on tRNA ${ }^{\text {Thr }}$ levels, enzymatic activity of electron transport chain complexes, membrane permeability, and the mitochondria-mediated generation of both reactive oxygen species (ROS) and adenosine triphosphate (ATP).

Results: We characterize mitochondrial genetic mutations in a three-generation Chinese family exhibiting signs of maternally inherited CHD. Of the 24 different family members in this pedigree we assessed, CHD was detected in 6, with variable severity and age of first appearance. When we sequenced the mitochondrial genomes of these individuals, we found a tRNA ${ }^{\text {Thr }} 15910 \mathrm{C}>$ T mutation of the Eastern Asian haplogroup M7b'c. This mutation is predicted to destabilize the strongly conserved (24C-10G) base-pairing, thereby disrupting tRNA ${ }^{\text {Thr }}$ functionality. When we performed Northern blotting, we detected we observed a 37.5\% reduction in tRNA ${ }^{\text {Thr }}$ levels at baseline in cybrid cell lines bearing the 15910C > T mutation. When we conducted western blot analysis, we detected a $\sim 24.96 \%$ decrease in mitochondrial translation rates in these same cells.
\end{abstract}

Conclusions: In the present report, Together these findings suggest a possible link between this 15910C $>$ T tRNA ${ }^{\text {Thr }}$ mutation and $\mathrm{CHD}$, potentially offering new avenues for future disease intervention.

Keywords: Coronary heart disease (CHD), Mitochondrial tRNA, Mutation, Chinese

\section{Background}

Different Cardiovascular diseases remain the most prominent cause of death globally, with coronary heart disease (CHD) remaining a highly complex and heterogeneous disease the onset of which is typically influenced by a range of environmental and genetic factors, although in some cases single gene mutations can drive disease $[1,2]$. While many studies to date have sought to identify nuclear genomic factors linked with CHD incidence, relatively few studies have specifically investigated $\mathrm{CHD}$ risk arising as a consequence of mitochondrial mutations [3-5]. Such investigations are important, as

\footnotetext{
*Correspondence: mitochondrion88@foxmail.com; up1006@163.com ${ }^{1}$ Department of Emergency, Affiliated hospital of Qingdao university, Jiangsu Road No. 16, Qingdao 266000, Shandong, China

Full list of author information is available at the end of the article
}

abnormal mitochondrial functionality has been found to be a potential driver of hypertension and other cardiovascular diseases [6, 7]. Multiple previous studies have identified linked between specific mitochondrial DNA (mtDNA) mutations and hypertension, including the tRNA $^{\text {Ile }} 4295 \mathrm{~A}>\mathrm{G}$ mutation, as well as the tRNA $^{\text {Ile }}$ 4263A > G, tRNA ${ }^{\text {Met }} /$ tRNA $^{\text {Gln }} 4401 \mathrm{~A}>\mathrm{G}$, and tRNA ${ }^{\text {Met }}$ $4435 \mathrm{~A}>\mathrm{G}$ mutations which were specifically linked to hypertension in Chinese individuals [8-11].

To explore additional mutations linked with $\mathrm{CHD}$ pathogenesis, we are conducting ongoing systematic screening efforts assessing mtDNA mutations among Chinese CHD patients. As a part of this effort, we have identified one three-generation family presenting with evidence of CHD transmitted matrilineal, with 6/24 analyzed adults in this family exhibiting CHD of varying

(c) The Author(s). 2019 Open Access This article is distributed under the terms of the Creative Commons Attribution 4.0 International License (http://creativecommons.org/licenses/by/4.0/), which permits unrestricted use, distribution, and reproduction in any medium, provided you give appropriate credit to the original author(s) and the source, provide a link to the Creative Commons license, and indicate if changes were made. The Creative Commons Public Domain Dedication waiver (http://creativecommons.org/publicdomain/zero/1.0/) applies to the data made available in this article, unless otherwise stated. 
severity. When we analyzed their mtDNA, we detected the presence of a tRNA ${ }^{\text {Thr }} 15910 \mathrm{C}>\mathrm{T}$ mutation of the M7b'c haplogroup. This mutation occurred in the stem region of this tRNA (conventional position 25) a site that is highly conserved and the mutation of which is predicted to result in structural and functional changes that have the potential to disrupt normal mitochondrial functionality. After identifying this mutation we followed up on its biological significance in cybrid cell lines bearing this mutation, measuring the effects of this $15910 \mathrm{C}>\mathrm{T}$ mutation on tRNA ${ }^{\text {Thr }}$ levels, enzymatic activity of electron transport chain complexes, membrane permeability, and the mitochondria-mediated generation of both reactive oxygen species (ROS) and adenosine triphosphate (ATP).

\section{Methods}

\section{Subjects}

Eighty genetically unrelated Han Chinese subjects with CHD including a three-generation Han Chinese family (Q5) were recruited from affiliated hospital of Qingdao university. In addition, 113 unrelated controls were also obtained from among volunteers in the same area. All participants provided informed consent, and underwent both clinical evaluation and blood sample collection. The Qingdao University ethics committee oversaw and approved this study.

\section{Assessment of risk factors}

Relevant risk factors in the present study included hypertension, hyperlipidemia, diabetes, a history of smoking, or a family history of CHD. Patient blood pressure was measured according to standard methods using the average of three readings. Hypertension was designated as a systolic blood pressure $\geq 140 \mathrm{mmHg}$ and/or a diastolic blood pressure $\geq 90 \mathrm{mmHg}$ as per JNC VI criteria. Diabetes was diagnoses in patients based on the presence of either a need for antidiabetic medications, or fasting blood glucose $>126 \mathrm{~g} / \mathrm{dL}$, as in previous reports.Any individuals who reported having used cigarettes within the past 12 months were designated smokers.

\section{Mitochondrial mutational assessment}

The Puregene DNA Isolation Kits (Biomega) was used to isolate total genomic DNA from study participants, after which mitochondrial genomic DNA was assessed via Southern blotting as in previous research. A total of 24 overlapping PCR fragments were generated and amplified in order to provide full coverage of the mitochondrial genome, using appropriate pairs of light/heavy strand primers used in previous studies. An ABI 3700 automated DNA sequencer was then employed to sequence each of these fragments following purification with a Big Dye Terminator Cycle sequencing reaction kit. The consensus revised Cambridge sequence (GenBank accession number: NC_012920) was then used for alignment of these sequenced fragments. Detection of the $15910 \mathrm{C}>\mathrm{T}$ mutation in family members, 80 unrelated CHD patients, and other controls was performed as in previous studies.

\section{Cell culture}

The Epstein-Barr virus was used to generate immortalized patient cell lines from the proband patient (III-3) bearing the $15910 \mathrm{C}>\mathrm{T}$ mutation, as well as from a control individual $(\mathrm{C} 2)$. These cells were cultured in RPMI 1640 containing 10\% FBS. Cybrid cells were generated by adapting previous protocols. Briefly, bromodeoxyuridine (BrdU)-resistant 143B.TK ${ }^{-}$cells were cultured in DMEM containing 5\% FBS, and the $\rho^{\circ} 206$ cell line lacking mtDNA derived from these same cells was also grown under these conditions in the presence of $50 \mu \mathrm{g}$ uridine $/ \mathrm{ml}$. The patient and control cell lines were then enucleated and fused with the $\rho^{\circ} 206$ cells. The resultant cybrid cell lines were then selected in uridine-free DMEM supplemented with BrdU, allowing for donorderived cybrid lines that could then be assessed for the m.15910C > T mutation, amounts of mtDNA, and other cellular genetic features. The resultant cybrid lines were maintained in DMEM containing 5\% FBS.

\section{Northern blotting}

TRIzol was used to isolate total mitochondrial RNA from knockdown or control cell lines, as in previous studies [12]. In brief, two micrograms of total mitochondrial RNA were electrophoresed through a $10 \%$ polyacrylamide/7 M urea gel in Tris-borate-Ethylenediaminetetraacetic acid (EDTA) buffer (TBE) (after heating the sample at $65^{\circ} \mathrm{C}$ for $10 \mathrm{~min}$ ), and then electroblotted onto a positively charged nylon membrane for the hybridization. Analysis with oligodeoxynucleotide probes. In total, we followed by transfer onto a positively charged membrane which was then combined with appropriate DIG oligodeoxynucleoside probes based on previously described approaches, using tRNA ${ }^{\text {Thr }}$, tRNA ${ }^{\text {His }}$, tRNA ${ }^{\text {Ala }}$, and tRNA ${ }^{\text {Glu }}$ utilized in previous studies $[3,12]$.

\section{Western blotting}

Western blotting was used to assess protein levels in cells, via first electrophoretically separating $20 \mu \mathrm{g}$ of protein from each sample via SDS-PAGE. These samples were then transferred onto PVDF membranes, which were then probed with primary antibodies against ND4, ND1, ND6, CYTB, ATP6, CO2, and VDAC. Secondary Affini Pure goat anti-mouse IgG and goat anti-rabbit IgG conjugated to peroxidase enzymes were then used to probe these blots, followed 
by use of an ECL system for chemiluminescent detection. Densitometric band quantification was then performed as in previous studies $[9,10]$.

\section{Measurements of enzymatic activity}

The complex I, II, III, and IV activities were assessed as in previous studies [12]. In brief, Citrate synthase activity was analyzed by the reduction of DTNB at $412 \mathrm{~nm}$ in the assay buffer. Complex I activity was determined by following the decrease in the absorbance due to the $\mathrm{NADH}$ oxidation at $340 \mathrm{~nm}$ in assay buffer. The activity of complex II was analyzed by tracking the secondary reduction of 2,6-dichlorophenolindophenol by decylubiquinone (DB) at $600 \mathrm{~nm}$ in the assay buffer. Complex III activity was determined by measuring the reduction of cytochrome $\mathrm{c}$ at $550 \mathrm{~nm}$ with reduced decylubiquinone in the assay buffer. Complex IV activity was measured by monitoring the oxidation of reduced cytochrome $\mathrm{c}$ as a decrease of absorbance at $550 \mathrm{~nm}$. Complex I-IV activities were normalized by citrate synthase activity $[3,12]$.

\section{Measuring ATP levels}

In order to assess ATP generation in cells, the Cell Titer-Glo Luminescent Cell Viability Assay kit (Promega) was used based on provided protocols [12]. In brief, after a $30 \mathrm{~min}$ equilibration of the cell plate to room temperature, $100 \mu \mathrm{l}$ of the assay reagent was added into each well with 20,000 cells and the content was mixed for 2 min on an orbital shaker to induce cell lysis. After 10 min incubation in room temperature, the luminescence was read on a microplate reader [12].

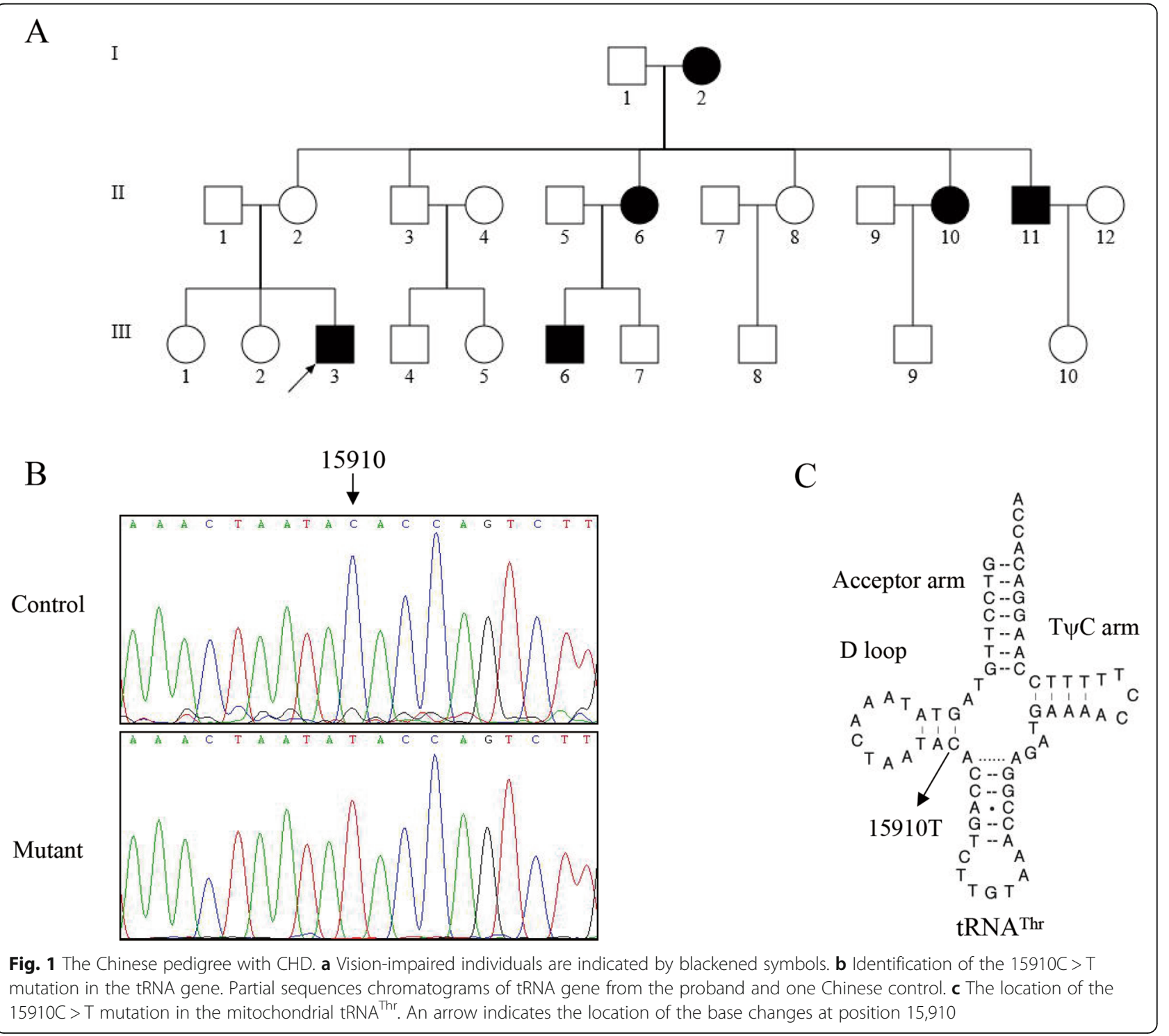


Table 1 Summary of clinical data for some members in a Chinese pedigree

\begin{tabular}{|c|c|c|c|c|c|c|c|}
\hline Subjects & Gender & Age of onset (years) & $\begin{array}{l}\text { Systolic pressure/Diastolic } \\
\text { pressure }(\mathrm{mmHg})\end{array}$ & ECG & $\begin{array}{l}\text { Ectent of CAD } \\
\text { narrow }(\%)\end{array}$ & $\begin{array}{l}\text { total cholestero } \\
(\mathrm{mg} / \mathrm{dl})\end{array}$ & $\begin{array}{l}\mathrm{LDL} \\
(\mathrm{mg} / \mathrm{dl})\end{array}$ \\
\hline$\overline{11-6}$ & $\mathrm{~F}$ & $60 \sim 65$ & $150 / 95$ & ischemia & 55 & 190 & 140 \\
\hline$\|-10$ & $\mathrm{~F}$ & $55 \sim 60$ & $140 / 90$ & ischemia & 50 & 220 & 145 \\
\hline$\|-11$ & M & $50 \sim 55$ & $138 / 85$ & ischemia & 50 & 210 & 150 \\
\hline|| $\mid-3$ & M & $40 \sim 45$ & $159 / 99$ & ischemia & 65 & 232 & 159 \\
\hline|| $\mid-6$ & M & $35 \sim 40$ & $145 / 90$ & ischemia & 50 & 187 & 140 \\
\hline
\end{tabular}

\section{Mitochondrial membrane potential measurements}

The JC-10 Assay Kit (Abcam) was used to measure mitochondrial membrane potential based on provided protocols as detailed elsewhere [3, 12]. In brief, cells were plated onto 96-well cell culture plate overnight in growth medium. In the first plated cell, JC-10 dyeloading solution was added for $30 \mathrm{~min}$ at $37^{\circ} \mathrm{C}, 5 \%$ $\mathrm{CO}_{2}$. Alternatively, the second plated cells were preincubated with $10 \mu \mathrm{M}$ of the FCCP for $30 \mathrm{~min}$ at $37^{\circ} \mathrm{C}$, $5 \% \mathrm{CO}_{2}$ prior to staining with JC-10 dye. Samples were measured at $\mathrm{Ex} / \mathrm{Em}=490 / 530$ and $490 / 590 \mathrm{~nm}$ with a microplate reader $[3,12]$.

\section{Assessment of ROS levels}

The MitoSOX Red Mitochondrial Superoxide Indicator (Invitrogen, M36008) was used to assess ROS production in live cells based on provided protocols as described previously $[3,12]$. In brief, approximately $2 \times 10^{6}$ cells of each cell line were harvested, resuspended in PBS, supplemented with $100 \mu \mathrm{M}$ of MitoSOX and $2 \%$ FBS. After incubation at $37^{\circ} \mathrm{C}$ for $20 \mathrm{~min}$. Finally, cells were resuspended. Samples were analyzed by the flow cytometer system, with an excitation at $488 \mathrm{~nm}$ and emission at $529 \mathrm{~nm} .10,000$ events were analyzed in each sample [3, 12].

\section{Statistical analysis}

Unpaired, two-tailed Student's t-tests were used to compare all values in this study. SPSS v17.0 and GraphPad Prism v 6.0 were used for all analysis, and $p<0.05$ was the significance threshold.

\section{Results}

\section{Clinical presentation}

The proband (Q5-III-3) was first diagnosed with CHD upon presenting at the Cardiology Clinic of affiliated hospital of Qingdao university, after which he underwent a full medical evaluation. The patient was diagnosed with hypertension $(159 / 99 \mathrm{mmHg})$, significant ischemia (65\% narrowing was evident upon coronary angiography), and high cholesterol (LDL-C $=159 \mathrm{mg} / \mathrm{dL}, \mathrm{TC}=$ $232 \mathrm{mg} / \mathrm{dL}$ ). The patient was not affected by any other comorbid conditions such as diabetes or neurological disease. When family members of this patients were evaluated for these same conditions, 5 were diagnosed with all three of these conditions (Fig. 1a and Table 1). In each case, any fathers with CHD had not transmitted it to their children, whereas mothers did transmit it, suggesting matrilineal inheritance consistent with mitochondrial involvement in this inherited CHD risk.

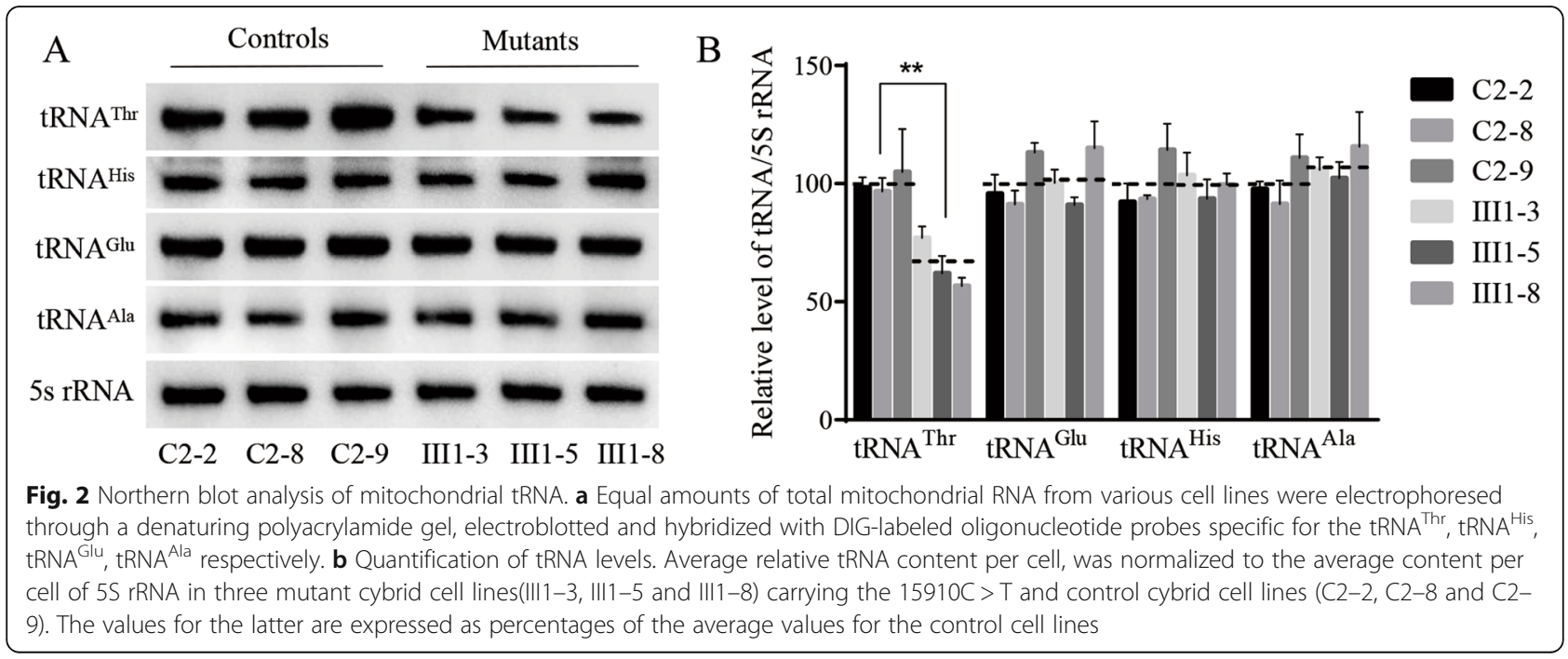




\section{Analysis of mitochondrial mutations}

To explore potential mitochondrial mutations linked with inherited CHD risk, we sequenced the mitochondrial genome of this proband patient Q5-III-3. A total of 45 mutations were evident in their mitochondrial genome upon comparison with the revised Cambridge consensus sequence (NC_012920), and the mitochondrial haplogroup for this patient was identified to be M7b'c (Fig. 2). As shown in Table 2, of these 45 variants, 19 were known silent variants, 14 were known D-loop variants, 8 were known missense mutations affecting protein-coding genes, 2 were known $12 \mathrm{~S}$ rRNA variants, 1 was a known $16 \mathrm{~s}$ rRNA variant, and one was a novel homoplasmy $15910 \mathrm{C}>\mathrm{T}$ mutation in the RRNA $^{\text {Thr }}$ gene (Fig. 1b). The detected missense mutations were as follows: 5460G $>$ A (Ala331Thr) in the ND2 gene, 7853G $>$ A (Val90Ile) in the $\mathrm{CO} 2$ gene, the $8701 \mathrm{~A}>\mathrm{G}$ (Thr59Ala) in the ATP6 gene, the 10398A $>$ G (Thr114Ala) in the ND3 gene, $12,811 \mathrm{~T}>\mathrm{C}$ (Tyr159His) in the ND5 gene, the 14766C $>\mathrm{T} \quad(\mathrm{Thr}>\mathrm{Ile}), 14978 \mathrm{~A}>\mathrm{G} \quad(\mathrm{Ile} 78 \mathrm{Val})$, and m.15326A $>$ G (Thr $>$ Ala) in the CYTB gene. We compared the variance at these mutated RNA residues phylogenetically across 16 different primate species, revealing this $\mathrm{tRNA}^{\mathrm{Thr}} 15910 \mathrm{C}>\mathrm{T}$ mutation to have a $100 \%$ conservation index across species, making it more likely to have functional significance when mutated as in this patient. Moreover, this mutation was also not detected when other 79 unrelated patients and 113 Chinese control subjects were analyzed.

\section{Mutation leads to decreased mitochondrial tRNA ${ }^{\text {Thr }}$ levels}

We next assessed how this $15910 \mathrm{C}>\mathrm{T}$ mutation altered the metabolism of tRNA ${ }^{\text {Thr }}$, subjecting cybrid cell lines bearing this mitochondrial mutation to Northern blotting using probes specific to this and 3 other tRNAs. We found that $\mathrm{tRNA}^{\mathrm{Thr}}$ levels in these mutant cybrid lines were significantly reduced relative to control wild type cells (Fig. 2), with baseline tRNA ${ }^{\text {Thr }}$ levels in these mutant cells being $65.25 \%$ of those in control cells, with $5 \mathrm{~S}$ RNA used for normalization purposes. In contrast, baseline tRNA ${ }^{\text {His }}$, tRNA ${ }^{\text {Ala }}$, and tRNA ${ }^{\text {Glu }}$ levels in these mutant cell lines were unchanged relative to control cells (102.13, 98.89, and 107.91\%, respectively).

\section{Mutation leads to reduced mitochondrial protein levels}

We next performed Western blotting to assess levels of the mtDNA-encoded components of the respiratory complex in cells bearing the $15910 \mathrm{C}>\mathrm{T}$ mutation or controls. As shown in Fig. 3, e found that mutant cells expressed mitochondrial protein levels that were 19.31 to $31.55 \%$ of those in control cells (average was $24.96 \%$; $P<0.05)$. These mutated cells also showed clear
Table 2 mtDNA variants in a Chinese family with CHD

\begin{tabular}{|c|c|c|c|c|c|}
\hline Gene & Position & Replacement & $\begin{array}{l}\text { AA } \\
\text { change }\end{array}$ & Conservation & $\begin{array}{l}\text { Previously } \\
\text { reported }\end{array}$ \\
\hline \multirow[t]{14}{*}{ D-loop } & 73 & $A-G$ & & & Yes \\
\hline & 143 & G-A & & & Yes \\
\hline & 150 & $C-T$ & & & Yes \\
\hline & 199 & $\mathrm{~T}-\mathrm{C}$ & & & Yes \\
\hline & 204 & $\mathrm{~T}-\mathrm{C}$ & & & Yes \\
\hline & 207 & G-A & & & Yes \\
\hline & 263 & $A-G$ & & & Yes \\
\hline & 310 & $\mathrm{~T}-\mathrm{C}$ & & & Yes \\
\hline & 489 & $\mathrm{~T}-\mathrm{C}$ & & & Yes \\
\hline & 16,129 & G-A & & & Yes \\
\hline & 16,189 & $\mathrm{~T}-\mathrm{C}$ & & & Yes \\
\hline & 16,223 & $C-T$ & & & Yes \\
\hline & 16,248 & $C-T$ & & & Yes \\
\hline & 16,297 & $\mathrm{~T}-\mathrm{C}$ & & & Yes \\
\hline \multirow[t]{2}{*}{ 12SrRNA } & 750 & $A-G$ & & & Yes \\
\hline & 1438 & $A-G$ & & & Yes \\
\hline 16SrRNA & 2706 & $A-G$ & & & Yes \\
\hline \multirow[t]{2}{*}{ ND1 } & 4071 & $C-T$ & & & Yes \\
\hline & 4164 & $A-G$ & & & Yes \\
\hline \multirow[t]{4}{*}{ ND2 } & 4679 & $\mathrm{~T}-\mathrm{C}$ & & & Yes \\
\hline & 4769 & $A-G$ & & & Yes \\
\hline & 5351 & $A-G$ & & & Yes \\
\hline & 5460 & G-A & Ala331Thr & $5.88 \%$ & Yes \\
\hline \multirow[t]{3}{*}{$\mathrm{CO} 1$} & 6455 & $C-T$ & & & Yes \\
\hline & 6680 & $\mathrm{~T}-\mathrm{C}$ & & & Yes \\
\hline & 7028 & $C-T$ & & & Yes \\
\hline \multirow[t]{2}{*}{$\mathrm{CO} 2$} & 7684 & $\mathrm{~T}-\mathrm{C}$ & & & Yes \\
\hline & 7853 & G-A & Val90lle & $29.41 \%$ & Yes \\
\hline ATP6 & 8701 & $A-G$ & Thr59Ala & $52.94 \%$ & Yes \\
\hline \multirow[t]{2}{*}{$\mathrm{CO} 3$} & 9540 & $\mathrm{~T}-\mathrm{C}$ & & & Yes \\
\hline & 9824 & $\mathrm{~T}-\mathrm{C}$ & & & Yes \\
\hline \multirow[t]{2}{*}{ ND3 } & 10,398 & $A-G$ & Thr114Ala & $41.18 \%$ & Yes \\
\hline & 10,400 & $C-T$ & & & Yes \\
\hline \multirow[t]{2}{*}{ ND4 } & 10,873 & $\mathrm{~T}-\mathrm{C}$ & & & Yes \\
\hline & 11,719 & G-A & & & Yes \\
\hline \multirow[t]{3}{*}{ ND5 } & 12,405 & $C-T$ & & & Yes \\
\hline & 12,705 & $C-T$ & & & Yes \\
\hline & 12,811 & $\mathrm{~T}-\mathrm{C}$ & Tyr159His & $64.71 \%$ & Yes \\
\hline \multirow[t]{5}{*}{ Cytb } & 14,766 & $C-T$ & Thr7lle & $47.06 \%$ & Yes \\
\hline & 14,783 & $\mathrm{~T}-\mathrm{C}$ & & & Yes \\
\hline & 14,978 & $A-G$ & Ile78Val & $47.06 \%$ & Yes \\
\hline & 15,043 & G-A & & & Yes \\
\hline & 15,301 & G-A & & & Yes \\
\hline
\end{tabular}


Table 2 mtDNA variants in a Chinese family with CHD (Continued)

\begin{tabular}{llllrl}
\hline Gene & Position & Replacement & $\begin{array}{l}\text { AA } \\
\text { change }\end{array}$ & Conservation & $\begin{array}{l}\text { Previously } \\
\text { reported }\end{array}$ \\
\hline & 15,326 & A-G & Thr194Ala & $52.94 \%$ & Yes \\
tRNA $^{\text {Thr }}$ & 15,910 & C-T & & $100 \%$ & No \\
\hline
\end{tabular}

As presented in online mitochondrial genome databases: www.mitomap.org and www.genpat.uu.se/mtDB

reductions $(18.71,26.56,37.52,33.00$ and $39.48 \%)$ in 5 polypeptides (ND4, ND1, ND6, CYTB and ATP6), while $\mathrm{CO} 2$ levels were not significantly reduced $(0.15 \%)$ relative to control cells.

\section{Mutation led to decreased complex I and III activity}

We further assessed the consequences of this m.15910C $>\mathrm{T}$ mutation on oxidative phosphorylation using isolated mitochondrial from our mutant and control cybrid cell lines. We found that complex I and III activity in the $15910 \mathrm{C}>\mathrm{T}$ mutant mitochondria was 66.72 , and $75.48 \%$ that of the activity observed in control cells, whereas no changes in complex II/IV activity were observed(Fig. 4a).

\section{Mutation leads to reduced mitochondrial ATP generation}

We further assessed the generation of ATP by wild type and mutant cells in an effort to better gauge how this mutation influenced oxidative phosphorylation. To test this, either glycolysis or oxidative phosphorylation were selectively induced in cells via culture with glucose, glucose + oligomycin, or 2deoxy-D-glucose + pyruvate. When cells could only engage in oxidative phosphorylation, mutant cells bearing the $15910 \mathrm{C}>\mathrm{T}$ mutation,exhibited ATP production that was 65.68-67.98\% (average: $67.37 \%$ ) of that in control cells(Fig. 4b).

\section{Mutation leads to increased ROS production}

We next assessed ROS production in our mutant cybrid cell lines via flow cytometry, comparing baseline staining intensity for each cell line to that upon oxidative stress in order to obtain a ratio corresponding to ROS generation. We observed somewhat increased ROS generation for our mutant cybrid cell lines bearing the $15910 \mathrm{C}>\mathrm{T}$ mutation, with ROS production 118.45-123.98\%, (average: $121.04 \%$ ) that of control cells (Fig. 4c).

\section{Discussion}

Mitochondrial DNA mutations have been associated with CHD in precious studies [13-15]. In this study, we offer evidence of a novel mitochondrial mutation which is linked to an elevated risk of CHD. This mutation was detected among adult matrilineally-related individuals in a three-generation Chinese family, with affected individuals presenting with CHD, hypertension and hyperlipidemia. This CHD risk was matrilineally inherited, and a mutational analysis revealed the presence of a $15910 \mathrm{C}>$ $\mathrm{T}$ mutation at the $\mathrm{C} 25$ position in the $\mathrm{tRNA}^{\mathrm{Thr}}$ sequence - a residue which is normally highly conserved and which is predicted to be important for tRNA stability(Fig. 1c). This mutations is predicted to destabilize the

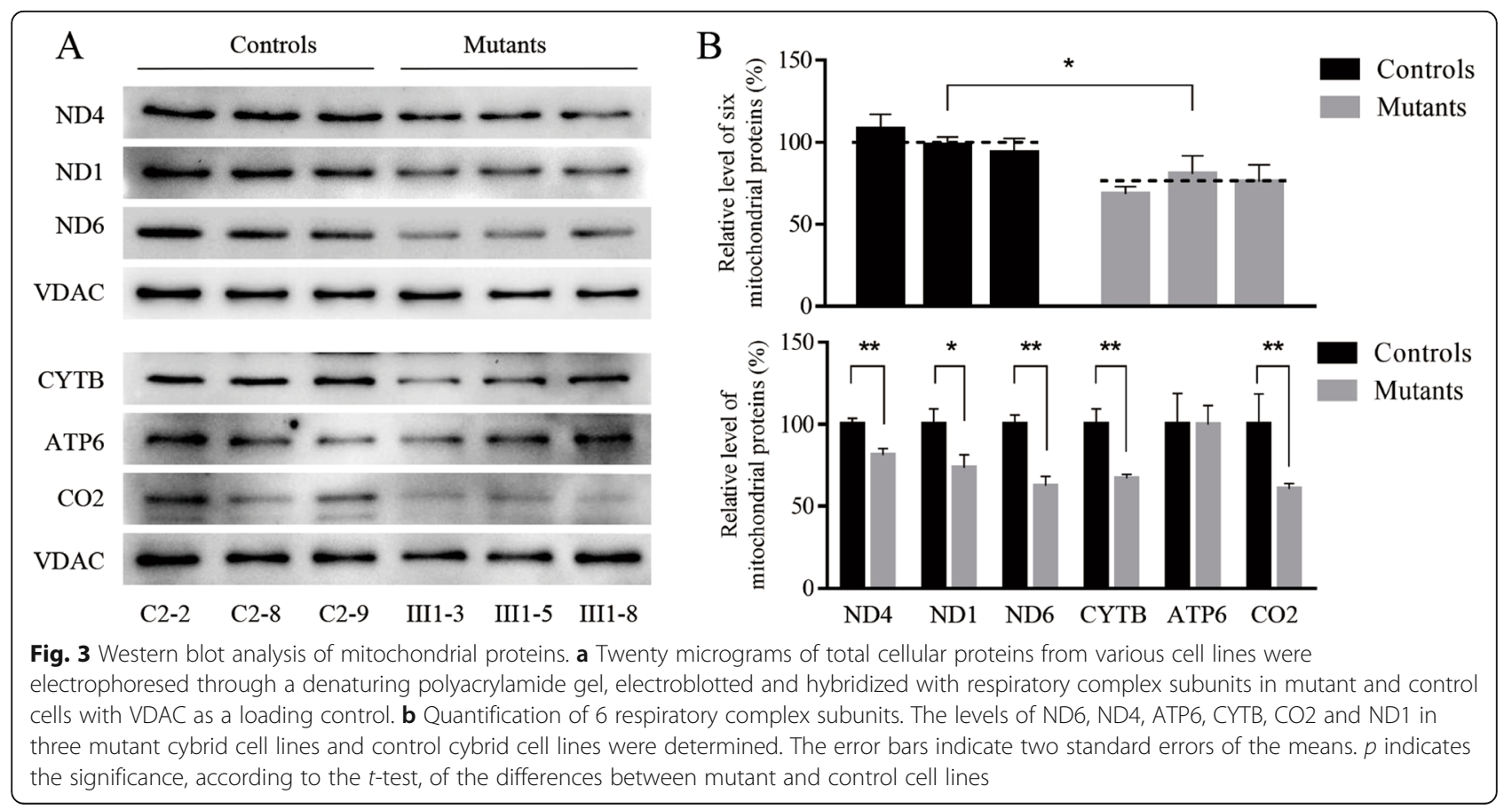




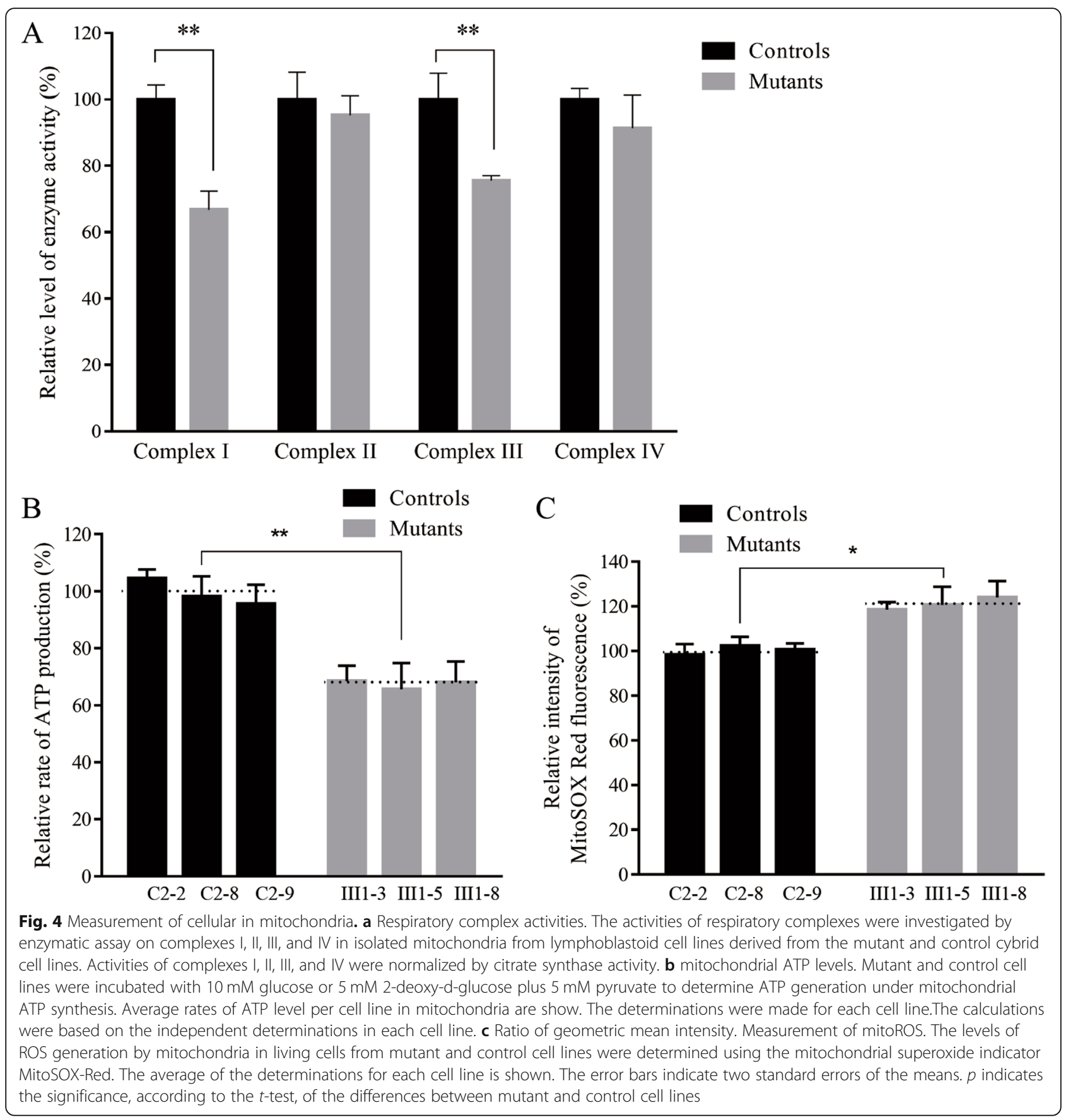

base-pairing at this site (25C-10G), potentially altering the secondary structure of this tRNA, as has previously been reported for the tRNA ${ }^{\text {Ile }} 4300 \mathrm{~A}>\mathrm{G}$ and tRNALeu(UUR) $3273 \mathrm{~T}>\mathrm{C}$ mutations [16, 17].

When cybrid cells bearing this mutation were generated, their baseline tRNA $^{\text {Thr }}$ levels were reduced by $37.5 \%$ relative to healthy control cells, suggesting that there may be a resultant destabilization of this mutated $\mathrm{tRNA}^{\text {Thr }}$ resulting in its more rapid degradation, as previously described previously such as the $3243 \mathrm{~A}>\mathrm{G}$ mutation of tRNA ${ }^{\text {Leu(UUR) }}$ [18-21]. As the mitochondrial dysfunction stemming from the $15910 \mathrm{C}>\mathrm{T}$ mutation was relatively mild, this suggests that this mutation alone is unlikely to cause CHD. As shown in Additional file 1: Table S1, we observed a $\sim 24.96 \%$ reduction in mitochondrial protein levels in cells bearing this mutation, and these cells als exhibited altered complex I/III activity which may coincide with increased electron leakage and 
elevated ROS production. In the present study, the reduced levels of mitochondrial proteins (an average decrease of $\sim 29 \%$ ) were comparable with the reduced rate of mitochondrial protein synthesis observed in cell lines bearing the hypertension-associated $\mathrm{m} .4435 \mathrm{~A}>\mathrm{G}$, $\mathrm{m} .4401 \mathrm{~A}>\mathrm{G}$ and $\mathrm{m} .4263 \mathrm{~A}>\mathrm{G}$ mutations [9-11]. Indeed, consistent with this we found that ROS production was elevated in cybrids expressing this $15910 \mathrm{C}>\mathrm{T}$ mutation. Such ROS production can lead to significant damage to cellular macromolecules including DNA and proteins, potentially leading to cellular dysfunction or apoptotic cell death which, if it were to occur in cardiac muscle cells, could contribute to the observed CHD phenotype, potnetially explaining how these mutations contribute to the observed matrilineal CHD, as hypertension-associated mitochondrial tRNA ${ }^{\mathrm{Ala}}$ m.5655A $>\mathrm{G}$ m.5587 T > C, tRNA ${ }^{\text {Leu(CUN) }}$ m.12280A $>$ G and tRNA ${ }^{\text {Met }}$ m.4467 C > A detailed previously [22-24].

As the $15910 \mathrm{C}>\mathrm{T}$ mutation was homoplasmic in nature in the study subjects, this suggests that the mutation is relatively mild, consistent with the limited changes in mitochondrial functionality observed herein. Even so, our study suggests that this gene mutation is linked to an elevated risk of CHD development, with the ultimate odds of CHD development likely depending on a combination of environmental, lifestyle, and nuclear genetic factors in concert with the observed mitochondrial dysfunction. Indeed, other mutations in nuclear genes may also contribute to mitochondrial dysfunction in patients bearing the $15910 \mathrm{C}>\mathrm{T}$ mutation, potentially resulting in the observed CHD phenotype. Moreover, the nuclear genetic or epigenetic factors may contribute to the development of clinical phenotype in subjects carrying the $15910 \mathrm{C}>\mathrm{T}$ mutation.

The study has several limitations. Firstly, this investigation is limited by relatively low number of patients included because the subjects only obtained from one hospital. Secondly, the homoplasmic form, mild mitochondrial dysfunction, late onset, and incomplete penetrance of CHD observed in this Chinese family carrying the $15910 \mathrm{C}>\mathrm{T}$ mutation suggest that the mutation is an inherited risk factor necessary for the development of CHD but may by itself be insufficient to produce a clinical phenotype. Finally, the tissue-specific effect of this $15910 \mathrm{C}>\mathrm{T}$ mutation may be attributed to the tissuespecific RNA metabolism or the involvement of nuclear modifier genes.

\section{Conclusions}

Our results suggest that the mitochondrial tRNA ${ }^{\text {Thr }}$ $15910 \mathrm{C}>\mathrm{T}$ mutation is linked to CHD incidence. This mutation leads to altered metabolism of this particular tRNA, thus resulting in abnormal mitochondrial functionality and enhanced ROS production. Other nuclear genetic mutations may also act in concert with the $15910 \mathrm{C}>\mathrm{T}$ mutation to amplify consequent mitochondrial dysfunction in affected patients, and extended ROS production in cardiovascular cells may be linked to $\mathrm{CHD}$ onset. Our results thus suggest a potential new mechanism liked to the underlying pathology of CHD, indicating future avenues for therapeutic research.

\section{Supplementary information}

Supplementary information accompanies this paper at https://doi.org/10. 1186/s12872-019-01284-4.

Additional file 1: Table S1. Summary of the mitochondrial functions in cybrid cell lines with control and mutant subjects.

\section{Abbreviations}

ATP: Adenosine triphosphate; CHD: Coronary heart disease; ROS: Reactive oxygen species

\section{Acknowledgements}

Not applicable.

\section{Authors' contributions}

$\mathrm{HL}$ and $\mathrm{ML}$ designed the experiments. $\mathrm{XZ}$ and $\mathrm{JH}$ collected the blood samples and extracted DNA from the blood samples. ZZ and YC analyzed the raw data. $\mathrm{ZZ}$ and $\mathrm{HL}$ wrote the manuscript. $\mathrm{HL}$ participate in revising the manuscript. All authors read and approved the final manuscript.

\section{Funding}

Not applicable.

\section{Availability of data and materials}

All data generated or analyzed during this study are included in this published article [and its supplementary information files].

Below are the links to the sequencing data generated in this study: https:// www.ncbi.nlm.nih.gov/bioproject/PRJNA591378.

\section{Ethics approval and consent to participate}

All subjects were willing to participate in the study and the written informed consent for clinical evaluations and genetic analysis were obtained from each participant. In addition, the protocol of the study was approved by the medical ethics committee of the Qingdao University.

\section{Consent for publication}

Written informed consent to publish this information was obtained from study participants. All the data are available for the consultation.

\section{Competing interests}

The authors declare that they have no competing interests.

\section{Author details}

${ }^{1}$ Department of Emergency, Affiliated hospital of Qingdao university, Jiangsu Road No. 16, Qingdao 266000, Shandong, China. ${ }^{2}$ Department of

Anesthesiology, Affiliated hospital of Qingdao university, Qingdao 266000,

Shandong, China. ${ }^{3}$ Department of ICU, Affiliated hospital of Qingdao university, Qingdao 266000, Shandong, China.

Received: 11 July 2019 Accepted: 27 November 2019

Published online: 16 December 2019

References

1. Wang T, Chen L, Yang T, Huang P, Wang L, Zhao L, Zhang S, Ye Z, Chen L, Zheng Z, Qin J. Congenital heart disease and risk of cardiovascular disease: a meta-analysis of cohort studies. J Am Heart Assoc. 2019;8(10):e012030.

2. Séguro F, Rabès JP, Taraszkiewicz D, Ruidavets JB, Bongard V, Ferrières J. Genetic diagnosis of familial hypercholesterolemia is associated with a premature and high coronary heart disease risk. Clin Cardiol. 2018;41(3):385-91. 
3. Jia Z, Zhang Y, Li Q, Ye Z, Liu Y, Fu C, Cang X, Wang M, Guan MX. A coronary artery disease-associated tRNA ${ }^{\text {Thr }}$ mutation altered mitochondrial function, apoptosis and angiogenesis. Nucleic Acids Res. 2019;47(4):2056-74.

4. Humphries SE, Drenos F, Ken-Dror G, Talmud PJ. Coronary heart disease risk prediction in the era of genome-wide association studies: current status and what the future holds. Circulation. 2010;121(20):2235-48.

5. Hegele RA. Genetic susceptibility to heart disease in Canada: lessons from patients with familial hypercholesterolemia. Genome. 2006:49(11):1343-50.

6. Corral-Debrinski M, Shoffner JM, Lott MT, Wallace DC. Association of mitochondrial DNA damage with aging and coronary atherosclerotic heart disease. Mutat Res. 1992;275(3-6):169-80.

7. Yang W, Ng FL, Chan K, Pu X, Poston RN, Ren M, An W, Zhang R, Wu J, Yan S, Situ H, He X, Chen Y, Tan X, Xiao Q, Tucker AT, Caulfield MJ, Ye S. Coronary-heart-disease-associated genetic variant at the COL4A1/COL4A2 locus affects COL4A1/COL4A2 expression, vascular cell survival, atherosclerotic plaque stability and risk of myocardial infarction. PLoS Genet. 2016:12(7):e1006127.

8. Li Z, Liu Y, Yang L, Wang S, Guan MX. Maternally inherited hypertension is associated with the mitochondrial tRNA(lle) A4295G mutation in a Chinese family. Biochem Biophys Res Commun. 2008;367(4):906-11.

9. Liu Y, Li R, Li Z, Wang XJ, Yang L, Wang S, Guan MX. Mitochondrial transfer RNA $^{\text {Met }} 4435 \mathrm{~A}>\mathrm{G}$ mutation is associated with maternally inherited hypertension in a Chinese pedigree. Hypertension. 2009;53(6):1083-90,

10. Li R, Liu Y, Li Z, Yang L, Wang S, Guan MX. Failures in mitochondrial tRNAMet and tRNAGIn metabolism caused by the novel 4401A>G mutation are involved in essential hypertension in a Han Chinese family. Hypertension. 2009;54(2):329-37.

11. Wang S, Li R, Fettermann A, Li Z, Qian Y, Liu Y, Wang X, Zhou A, Mo JQ, Yang L, Jiang P, Taschner A, Rossmanith W, Guan MX. Maternally inherited essential hypertension is associated with the novel $4263 \mathrm{~A}>\mathrm{G}$ mutation in the mitochondrial tRNAlle gene in a large Han Chinese family. Circ Res. 2011;108(7):862-70.

12. Zhou M, Wang $M$, Xue L, Lin Z, He Q, Shi W, Chen Y, Jin X, Li H, Jiang $P$, Guan MX. A hypertension-associated mitochondrial DNA mutation alters the tertiary interaction and function of tRNALeu(UUR). J Biol Chem. 2017; 292(34):13934-46.

13. Sobenin IA, Sazonova MA, Ivanova MM, Zhelankin AV, Myasoedova VA Postnov AY, Nurbaev SD, Bobryshev YV, Orekhov AN. Mutation C3256T of mitochondrial genome in white blood cells: novel genetic marker of atherosclerosis and coronary heart disease. PLoS One. 2012;7(10):e46573.

14. Mitrofanov KY, Zhelankin AV, Shiganova GM, Sazonova MA, Bobryshev YV, Postnov AY, Sobenin IAIA, Orekhov AN. Analysis of mitochondrial DNA heteroplasmic mutations A1555G, C3256T, T3336C, C5178A, G12315A G13513A, G14459A, G14846A and G15059A in CHD patients with the history of myocardial infarction. Exp Mol Pathol. 2016:100(1):87-91.

15. Matam K, Shaik NA, Aggarwal S, Diwale S, Banaganapalli B, Al-Aama JY, Elango R, Rao P. Hasan Q. Evidence for the presence of somatic mitochondrial DNA mutations in right atrial appendage tissues of coronary artery disease patients. Mol Gen Genomics. 2014;289(4):533-40.

16. Taylor RW, Giordano C, Davidson MM, d'Amati G, Bain H, Hayes CM, Leonard H, Barron MJ, Casali C, Santorelli FM, Hirano M, Lightowlers RN, DiMauro S, Turnbull DM. A homoplasmic mitochondrial transfer ribonucleic acid mutation as a cause of maternally inherited hypertrophic cardiomyopathy. J Am Coll Cardiol. 2003;41(10):1786-96.

17. Campos Y, Gámez J, García A, Andreu AL, Rubio JC, Martín MA, del Hoyo P, Navarro C, Cervera C, Garesse R, Arenas J. A new mtDNA mutation in the tRNA(Leu(UUR)) gene associated with ocular myopathy. Neuromuscul Disord. 2001;11(5):477-80.

18. Hung PC, Wang HS, Chung HT, Hwang MS, Ro LS. Pulmonary hypertension in a child with mitochondrial A3243G point mutation. Brain and Development. 2012;34(10):866-8.

19. Liu CH, Chang CH, Kuo HC, Ro LS, Liou CW, Wei YH, Huang CC. Prognosis of symptomatic patients with the A3243G mutation of mitochondrial DNA. J Formos Med Assoc. 2012:111(9):489-94.

20. Lu J, Wang D, Li R, Li W, Ji J, Zhao J, Ye W, Yang L, Qian Y, Zhu Y, Guan MX. Maternally transmitted diabetes mellitus associated with the mitochondrial tRNA(Leu(UUR)) A3243G mutation in a four-generation Han Chinese family. Biochem Biophys Res Commun. 2006:348(1):115-9.

21. Qin $Y$, Xue L, Jiang P, Xu M, He Y, Shi S, Huang Y, He J, Mo JQ, Guan MX. Mitochondrial tRNA variants in Chinese subjects with coronary heart disease. J Am Heart Assoc. 2014;3(1):e000437.1.
22. Jiang $P$, Wang $M$, Xue L, Xiao $Y$, Yu J, Wang $H$, Yao J, Liu $H$, Peng $Y$, Liu H, Li H, Chen Y, Guan MX. A hypertension-associated tRNAAla mutation alters tRNA metabolism and mitochondrial function. Mol Cell Biol. 2016;36(14):1920-30.

23. Lin L, Cui $P$, Qiu Z, Wang M, Yu Y, Wang J, Sun Q, Zhao H. The mitochondrial tRNAAla 5587T>C and tRNALeu(CUN) 12280A>G mutations may be associated with hypertension in a Chinese family. Exp Ther Med. 2019;17(3):1855-62.

24. Liu Y, Li Y, Zhu C, Tian L, Guan M, Chen Y. Mitochondrial biogenesis dysfunction and metabolic dysfunction from a novel mitochondrial tRNAMet 4467 C >a mutation in a Han Chinese family with maternally inherited hypertension. Sci Rep. 2017;7(1):3034

\section{Publisher's Note}

Springer Nature remains neutral with regard to jurisdictional claims in published maps and institutional affiliations.
Ready to submit your research? Choose BMC and benefit from:

- fast, convenient online submission

- thorough peer review by experienced researchers in your field

- rapid publication on acceptance

- support for research data, including large and complex data types

- gold Open Access which fosters wider collaboration and increased citations

- maximum visibility for your research: over $100 \mathrm{M}$ website views per year

At $\mathrm{BMC}$, research is always in progress.

Learn more biomedcentral.com/submissions 